\title{
Główne problemy opodatkowania przychodu osób fizycznych z działalności rolniczej w Polsce ${ }^{1}$
}

\begin{abstract}
Taxation of individuals' revenues from agricultural activity in Poland: The article discusses the main problems concerning the taxation of income from agricultural activity in Poland. The first section presents the agricultural tax, which takes into account both the income from agricultural production and land used for this purpose. The second section is devoted to the taxation of revenues derived from specialized agricultural activity, which are subject to personal income tax. This duality causes incoherence and raises significant legal dilemmas. Therefore, the authors propose alternatives and recommend the reform of income taxation on agricultural activity.

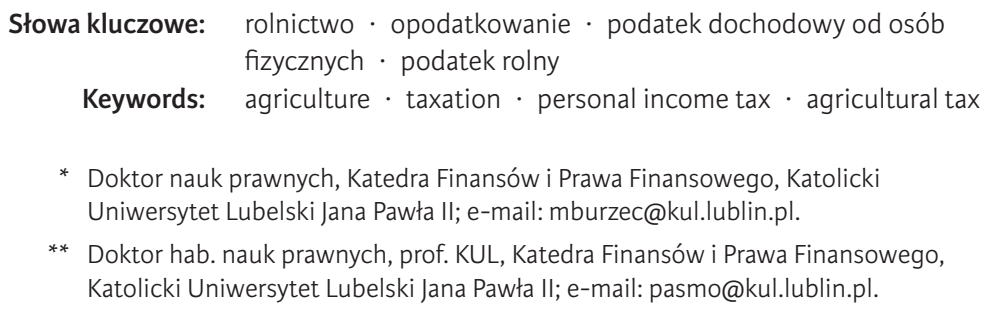

\section{Uwagi ogólne}

W zależności od znaczenia rolnictwa w gospodarce, warunków naturalnych, ukształtowania terenu, a także stopnia zaawansowania technologicznego wyodrębnić można różne koncepcje opodatkowania działalności rolniczej. Zasadniczo działalność rolnicza prowadzona przez osoby fizyczne może być opodatkowana podatkiem dochodowym bądź podatkiem gruntowym². Pierwsza

${ }^{1}$ Niniejszy artykuł obejmuje badania prowadzone w ramach projektu sfinansowanego ze środków Narodowego Centrum Nauki przyznanych na podstawie decyzji numer DEC-2013/09/B/HS5/04503.Tytuł projektu „Nowy model opodatkowania rolnictwa w Polsce”.

2 Może być ona także obciążona podatkami pośrednimi, jednakże z uwagi na charakter opracowania kwestie te zostały celowo pominięte. 
koncepcja jest powszechnie stosowana $\mathrm{w}$ państwach wysoko rozwiniętych, gdzie rolnictwo odgrywa mniej istotną rolę w gospodarce ${ }^{3}$. Koncepcja opodatkowania podatkiem gruntowym jest nieco starsza, w Europie szeroko stosowana była w XIX wieku, a także w XX wieku w państwach socjalistycznych ${ }^{4}$. $\mathrm{W}$ zależności od systemu podatkowego istniejącego $\mathrm{w}$ danym państwie, podatek, który obciąża działalność rolniczą, może być nakładany w głównej mierze na dochód lub przychód. Opodatkowanie przychodu, co do zasady najczęściej ma miejsce $\mathrm{w}$ podatkach gruntowych, a także niekiedy $\mathrm{w}$ formach uproszczonych przy opodatkowaniu podatkiem dochodowym od osób fizycznych ${ }^{5}$. Zdarza się, że ze względu na uwarunkowania kulturowe czy społeczno-gospodarcze niektóre państwa rezygnują całkowicie ${ }^{6}$ lub częściowo ${ }^{7} \mathrm{z}$ opodatkowania produkcji rolnej. W każdym wariancie chodzi o stworzenie racjonalnego systemu podatkowego, który uwzględniałby zarówno interes fiskalny państwa, jak i specyfikę produkcji rolnej.

W Polsce w zakresie opodatkowania działalności rolniczej istnieje swoisty dualizm. Tradycyjna działalność rolnicza została wyłączona z opodatkowania podatkiem dochodowym ${ }^{8}$. Przyjmuje się, że daniną, która w sposób kompleksowy uwzględnia zarówno uzyskiwane przychody z tytułu produkcji rolnej, jak i wykorzystywane w tym celu grunty, jest podatek rolny'. Przychody (dochody) osiągane ze specjalistycznej działalności rolniczej stanowią przedmiot opodatkowania w podatku dochodowym od osób fizycznych ${ }^{10}$ lub podatku dochodowym od osób prawnych ${ }^{11}$. Ograniczenia objętości artykułu nie pozwalają na kompleksowe omówienie tej skomplikowanej i ważkiej społecznie tematyki.

3 Zob. H. van der Veen, H. van der Meulen, K. van Bommel, B. Doorneweert, Exploring agricultural taxation in Europe, LEI, Haga 2007.

${ }_{4}$ Zob. E. Taylor, Reforma podatku gruntowego $w$ Polsce, S.A. Krzyżanowski, Kraków 1919; H. Reniger, Problem podstawy wymiaru w socjalistycznym podatku rolniczym okresu przejściowego, Państwowe Wydawnictwo Naukowe, Torun 1963.

5 A. Pauličková, Priame dane v Slovenskej republike, Eurounion, Bratislava 2001, s. 87-92.

6 Iran [w:] Taxation and Investment in Asia, IBFD, Amsterdam 2008, s. 58.

7 Przykładowo w Portugalii wyłączeniu podlega całkowita wartość kwot uzyskanych przez podatnika w roku podatkowym ( $\mathrm{w}$ tym podlegające zwolnieniu), która nie przekracza na gospodarstwo domowe czteroipółkrotności rocznej wartości tak zwanego Indeksu Wsparcia Społecznego (Indexante dos Apoios Sociais). W 2017 r. kwota ta wynosiła 22751,28 euro.

8 Przez tradycyjną działalność rolniczą należy rozumieć prowadzenie takiej produkcji rolnej, gdzie grunt wykorzystywany jest jako środek produkcji.

9 Ustawa z 15 listopada 1984 r. o podatku rolnym, t.j. Dz.U. 2017, poz. 1892; dalej: ustawa o podatku rolnym lub u.p.r.

10 Ustawa z 26 lipca 1991 r. o podatku dochodowym od osób fizycznych, t.j. Dz.U. 2016, poz. 2032, ze zm.; dalej: ustawa o podatku dochodowym od osób fizycznych.

11 Ustawa z 15 lipca 1992 r. o podatku dochodowym od osób prawnych, t.j. Dz.U. 2017, poz. 2343, ze zm. 
Warto natomiast skupić się na jej najważniejszych elementach statuujących i determinujących główne założenia opodatkowania analizowanej sfery aktywności podatników. W kontekście wspomnianego dualizmu podatkowego konieczna staje się weryfikacja charakteru prawnego podatku rolnego - przede wszystkim przez pryzmat tych elementów konstrukcyjnych, które wskazują na przychodowy charakter tej daniny. Kluczowe znaczenie ma także relacja wskazanych elementów i regulacji podatku dochodowego. Wyraźna jest przy tym niespójność polskich regulacji prawnych z ogólnymi zasadami, obowiązującymi w tych systemach podatkowych, które do opodatkowania działalności rolniczej wykorzystują daniny, w których podstawa opodatkowania ustalana jest na podstawie znamion zewnętrznych lub zbliżonego do nich dochodu katastralnego. To wszystko skłania do podjęcia próby projekcji kierunków reformy opodatkowania dochodów osiąganych z tytułu prowadzenia działalności rolniczej.

\section{Aspekt opodatkowania przychodów w podatku rolnym}

W literaturze przedmiotu charakter podatku rolnego budzi wiele wątpliwości. Jest on bowiem kwalifikowany jako podatek majątkowy ${ }^{12}$ lub też podatek przychodowo-majątkowy, a niekiedy nawet przychodowo-dochodowo-majątkowy ${ }^{13}$. O skomplikowanym charakterze tej daniny publicznej świadczy to, że wywodzi się ona $\mathrm{z}$ koncepcji typowego podatku gruntowego, powszechnie wprowadzanego pod koniec XIX wieku w państwach europejskich. Jego istotą było opodatkowanie przychodów uzyskiwanych z działalności rolniczej na podstawie tzw. znamion zewnętrznych. Mimo że podatek rolny obowiązuje w polskim systemie podatkowym od połowy lat 80. ubiegłego wieku, to współczesna konstrukcja podatku nie uległa zbyt dużym zmianom. W praktyce nadal jest on jedyną daniną, która obciąża podmioty prowadzące tradycyjną działalność rolniczą. Nie bez znaczenia pozostaje w związku z tym wydajność fiskalna. Nie dziwi więc, że zarówno sam podatek, jak i jego konstrukcja budzą liczne kontrowersje.

Przedmiotem opodatkowania w podatku rolnym są grunty sklasyfikowane w ewidencji gruntów i budynków jako użytki rolne, $\mathrm{z}$ wyłączeniem tych gruntów, które zajęte są na prowadzenie działalności innej niż rolnicza (art. 1 ust 1 u.p.r.). Wydaje się zatem, że podatek rolny powinien być tą daniną, która nakładana jest na podmioty prowadzące działalność rolniczą i które posiadają grunty rolne. Wprawdzie w ustawie o podatku rolnym zawarta została defini-

12 A. Hanusz, P. Czerski, Gminne podatki i opłaty lokalne, Zakamycze, Kraków 2004, s. 54; W. Pietrasiewicz, Podatek rolny [w:] Prawo podatkowe przedsiębiorców, red. H. Litwińczuk, Wolters Kluwer, Warszawa 2013, s. 766-767.

13 L. Etel, Podatki przychodowo-dochodowo-majątkowe [w:] System prawa finansowego, t. 3, red. L. Etel, C.H. Beck, Warszawa 2010, s. 305 i n.; A. Gorgol, Revenue factor as a feature of the agricultural tax [w:] Essential problems with taxation of agriculture, red. M. Burzec, P. Smoleń, Wydawnictwo KUL, Lublin 2017, s. 101-114. 
cja działalności rolniczej (art. 2 ust. 1 u.p.r.), jednakże praktycznie nie ma ona wpływu zarówno na przedmiot, jak i podmiot opodatkowania. W konstrukcji podatku zabrakło bowiem odpowiednich regulacji, które w większym stopniu kładłyby nacisk na przedmiot opodatkowania, a który powinien być ściśle związany z działalnością rolniczą. Brak jest wskazania, że przedmiotem opodatkowania są grunty odpowiednio sklasyfikowane w ewidencji gruntów i budynków, na których prowadzona jest działalność rolnicza. Zgodnie z obowiązującymi przepisami prawa podatnikami podatku rolnego mogą być zarówno podmioty, które prowadzą działalność rolniczą, jak i podmioty, które nie są zainteresowane prowadzeniem produkcji rolnej, a jedynie posiadają grunty odpowiednio sklasyfikowane w ewidencji gruntów i budynków. Powyższy problem powinno rozwiązać właściwe sformułowanie pojęcia "gospodarstwa rolnego". Jednakże ustawa o podatku rolnym rozumie go jako grunty sklasyfikowane w ewidencji gruntów i budynków jako użytki rolne o powierzchni przekraczającej jeden hektar fizyczny bądź jeden hektar przeliczeniowy. Przyjęcie takiego rozwiązania wyklucza możliwość uznania za gospodarstwo rolne gruntów, których powierzchnia jest mniejsza niż 1 ha lub 1 ha przeliczeniowy, mimo że mogą one służyć do prowadzenia działalności rolniczej. Tym samym z jednej strony działalność polegająca na produkcji roślinnej lub zwierzęcej na obszarze mniejszym niż 1 ha lub 1 ha przeliczeniowy będzie mogła zostać uznana za działalność rolniczą, z drugiej jednak w rozumieniu ustawy o podatku rolnym tego typu czynność nie będzie prowadzona w ramach gospodarstwa rolnego, gdyż niespełniony zostanie warunek normy obszarowej. Konsekwencją takiego stanu rzeczy będzie zastosowanie wyższej stawki podatkowej w podatku rolnym, wynoszącej równowartość pieniężną 5 q, a nie 2,5 q żyta. W związku z tym zauważyć należy brak konsekwencji ustawodawcy. Podmiot, który w ogóle nie prowadzi działalności rolniczej, jednakże posiada grunty o powierzchni większej niż 1 ha przeliczeniowy lub 1 ha fizyczny, w świetle przepisów ustawy o podatku rolnym będzie posiadał gospodarstwo rolne i tym samym jego obciążenie podatkowe, mimo tego że nie prowadzi działalności rolniczej, będzie niższe.

Kolejną wadą konstrukcji podatku rolnego jest ukształtowanie jego podstawy opodatkowania. W stosunku do gruntów wchodzących w skład gospodarstwa rolnego została ona oparta na powierzchni wyrażonej w hektarach przeliczeniowych (art. 4 ust. 1 pkt 1 u.p.r.). Zasadniczym celem wprowadzenia tej jednostki do konstrukcji podatku było uwzględnienie różnic w przychodowości poszczególnych gospodarstw. W tym wypadku ustawodawca ustalił, że czynnikiem mającym istotny wpływ na wysokość osiąganych przychodów z produkcji jest nie tylko wielkość gospodarstwa, ale także jego położenie geograficzne, warunki klimatyczne, uwarunkowania hydrologiczne panujące na danym obszarze, rodzaj użytków rolnych czy też jakość gruntów. Hektar przeliczeniowy wyrażający przychodowość gospodarstwa rolnego 
uzależniony został od takich czynników, jak rodzaj i klasy użytków rolnych, a także właściwe zaliczenie do okręgu podatkowego. Ustalone zostały 4 okręgi podatkowe, do których zalicza się gminy oraz miasta. Odpowiednie przypisanie każdej jednostki administracyjnej do jednego z okręgów podatkowych dokonywane jest na podstawie czynników ekonomicznych i produkcyjno-klimatycznych (art. 4 ust. 4 u.p.r.). Istnienie powyższych kryteriów, które w istotny sposób wpływają na hektar przeliczeniowy, wydaje się konieczne w tych podatkach, w których podstawa opodatkowania ustalana jest według znamion zewnętrznych. Należy także zauważyć, że wskazane czynniki mogą mieć zastosowanie nie tylko w stosunku do archaicznej grupy tzw. podatków gruntowych, do której zaliczyć należy również polski podatek rolny, ale także podatków dochodowych, w których to konstrukcjach wobec braku woli ustawodawcy do wniknięcia w sytuację dochodową danego podatnika (gospodarstwa rolnego) przyjmuje się jako podstawę opodatkowania tzw. dochód katastralny. Sytuacja taka ma miejsce we Włoszech, a do niedawna we Francji ${ }^{14}$ i w Niemczech. Pamiętać jednak należy, że w wymienionych państwach ustalenie dochodu następuje lub następowało w wyniku żmudnego procesu przypisania przeciętnego szacunkowego dochodu do poszczególnej parceli stanowiącej zazwyczaj jednostkę o powierzchni 1 ha ${ }^{15}$ lub (jak miało to miejsce w Niemczech) wysokość szacunkowego dochodu uzależniona była od wartości gruntu rolnego wynikającej z katastru nieruchomości ${ }^{16}$.

Istotnym mankamentem ustalania podstawy opodatkowania przy wykorzystaniu znamion zewnętrznych lub tzw. dochodu katastralnego jest nieuwzględnianie produkcji zwierzęcej. Stąd też wydaje się konieczne wprowadzenie takich mechanizmów, dzięki którym opodatkowaniu będą podlegały zarówno przychody/dochody z działalności rolniczej, polegającej na uprawach roślin, jak i chowie lub hodowli zwierząt. Jest to możliwe przez wyodrębnienie z tradycyjnej działalności rolniczej tzw. specjalistycznej produkcji rolnej obejmującej produkcję zwierzęcą. Innym rozwiązaniem jest wskazanie na limity produkcyjne/hodowlane, które ma dany grunt ${ }^{17}$. Przyjmuje się, że na okre-

${ }^{14}$ J. Lamarque, O. Négrin, L. Ayrault, Droit fiscal général, LexisNexis, Paris 2016, s. 1079.

15 N. D’Amati, La legge sulla perequazione fondiaria e l'emergere del reddito agrario [w:] L'impresa agraria tra fisco, problem ambientali e programmazione territoriale, red. N. D'Amati, Cacucci Editore, Bari 2006, s. 9-34; S. Muleo, Impresa agraria ed imposizione reddituale, Giuffrè Editore, Milano 2005, s. 121 i n., oraz A. Achard, Les prélèvements obligatories sur l'exploatation agricole, Educagri, Dijon 2009, s. 47-49.

16 Steurergesetze 2012, Boorberg, Stuttgart 2012, s. 410.

17 Tak jak ma to miejsce w konstrukcji austriackiego i niemieckiego podatku dochodowego w ramach ryczałtowej metody ustalania dochodu. Szerzej zob.: M. Aghata, Einkünfte aus Land- und Forstwirtschaft [w:] Besteuerung der Land- und Forstwirtschaft, red. M. Aghata i in., NWB Verlag, Herne 2014, s. 77-79, a także H. Peyerl, Unternehmensgründung und laufende Unternehmensführung [w:] Rechtsformwahl in der Land-und Forstwirtschaft. 
ślonej jednostce powierzchni można wyhodować, w zależności od gatunku zwierząt, daną liczbę sztuk. Liczba ta powinna wynikać z możliwości produkcyjnych gruntu w zakresie zapewnienia pokarmu niezbędnego do wyżywienia hodowanych osobników. Tym samym hodowla i chów zwierząt w rozmiarach większych niż ustawowe limity nie powinna mieścić się w zakresie definicji tradycyjnej działalności rolniczej. Z uwagi na przekroczenie potencjału produkcyjnego gruntu należałoby ją zakwalifikować jako pozarolniczą działalność gospodarczą lub stworzyć w sposób odrębny specjalne normy dochodu. Pamiętać jednak należy, że w tym wypadku ustawodawca powinien zróżnicować limity w zależności od rodzaju prowadzonej hodowli lub chowu zwierząt.

Na kanwie powyższych rozważań należy zauważyć, że w podstawie opodatkowania polskiego podatku rolnego uwzględniona została wyłącznie produkcja roślinna. Ustawodawca wydaje się nie być zainteresowany tym, aby podstawę opodatkowania w podatku rolnym rozszerzyć o produkcję zwierzęcą, wprowadzając limity odnoszące się do potencjału gruntu, lub też uznać hodowlę lub chów zwierząt prowadzoną także $\mathrm{w}$ ramach gospodarstwa rolnego za specjalistyczną produkcję rolną. O braku zainteresowania opodatkowaniem produkcji zwierzęcej świadczy także konstrukcja stawki podatkowej, która w obecnym kształcie wskazuje na przychodowy charakter podatku rolnego. Jej wysokość wynosząca 2,5 q dla gruntów wchodzących w skład gospodarstw rolnych, a dla pozostałych gruntów $5 \mathrm{q}$, uzależniona została od aktualnej ceny kwintala żyta obliczonej według średniej ceny zakupu za 11 kwartałów poprzedzających kwartał poprzedzający rok podatkowy (art. 6 ust. 1 oraz ust. 2 u.p.r.). Oznacza to, że konstrukcja stawki nie ma związku z produkcją zwierzęcą. Ponadto zauważyć należy, że uzależnienie wysokości stawki podatkowej od ceny wyłącznie jednego produktu roślinnego powoduje, że produkcja roślinna nie jest opodatkowana w sposób właściwy ${ }^{18}$. Istotne jest również to, że współcześnie produkcja żyta w całości upraw polowych w Polsce odgrywa mniejszą rolę niż w latach 80 . XX wieku ${ }^{19}$. Tym samym w obecnym stanie prawnym stawka podatkowa, o ile dany podmiot nie uprawia żyta, ma niewielki związek z prowadzoną produkcją roślinną. Paradoksalnie jednak w konstrukcji omawianej daniny, mimo faktu, że nie obciąża ona produkcji zwierzęcej, znalazła się ulga inwestycyjna, która pozwala na obniżenie podatku tym podatnikom, którzy między innymi dokonują modernizacji budynków inwentarskich, czyli takich, które są związane z chowem, hodowlą i utrzymaniem zwierząt gospodarskich

Gestalung und Besteuerung, P. Brauner, H. Peyerl, W. Pum, C. Urban, Verlag Österreich, Wien 2015, s. 42-45.

18 J. Bieluk, Cena żyta jako miernik wysokości podatku rolnego, „Studia Iuridica Agraria” 2000, nr 1, s. 173-178.

19 W 2015 r. uprawy żyta zajmowały dopiero dziewiąte miejsce wśród wszystkich upraw polowych prowadzonych w Polsce. Zob. Główny Urząd Statystyczny, Rolnictwo w 2015 roku, Warszawa 2016, s. 83. 
oraz pełnią funkcję magazynową w zakresie prowadzonej produkcji zwierzęcej (art. 13 u.p.r.). Być może jest to relikt polityki prowadzonej w latach 80. XX wieku, kiedy to zwiększenie produkcji zwierzęcej było jednym z priorytetów gospodarski socjalistycznej. Współcześnie brak jest jednak racjonalnych argumentów, aby promować względem produkcji roślinnej produkcję zwierzęcą, nie tylko nie uwzględniając jej w podstawie opodatkowania, ale także umożliwiając obniżenie kwoty podatku przez zastosowanie ulgi inwestycyjnej.

Należy wskazać także na dwie pozostałe ulgi występujące w podatku rolnym. Mają one charakter korygujący. Ich znaczenie ogrywa istotną rolę, gdyż w podatkach, w których przychody ustalane są na podstawie znamion zewnętrznych, brak jest możliwości korekty uzyskanego przychodu/dochodu w inny sposób niż przez zastosowanie ustawowej preferencji. Pierwsza $z$ nich, tzw. ulga z tytułu klęski żywiołowej, polega na zaniechaniu poboru podatku lub zaniechaniu ustalenia podatku w sytuacji, gdy podatnik poniesie straty $\mathrm{w}$ prowadzonej produkcji w wyniku wystąpienia klęski żywiołowej (art. 13c u.p.r.). Podkreślić należy, że ulgi takie są powszechnie stosowane w podatkach dochodowych, w których podstawa opodatkowania ustalana jest według tzw. dochodu katastralnego (Włochy ${ }^{20}$, Francja ${ }^{21}$ ). Mają one istotne znaczenie, gdyż podatnik nie ma możliwości odliczenia poniesionych w trakcie roku strat wynikających z nadzwyczajnych zjawisk atmosferycznych. Ponadto może być ona także stosowana wówczas, gdy podstawa opodatkowania podatku dochodowego określana jest zgodnie z przyjętymi normami szacunkowymi dochodu rocznego (tak jak ma to miejsce w Rumunii) ${ }^{22}$. W Polsce z dniem 1 stycznia 2016 r., w wyniku dokonanej nowelizacji ustawy o podatku rolnym ulga taka straciła całkowicie rację bytu. Wynika to $\mathrm{z}$ faktu, że przyznanie jej zostało uzależnione od wprowadzenia przez Radę Ministrów w drodze rozporządzenia stanu klęski żywiołowej na obszarze, na którym wystąpiła klęska, a także na obszarze, na którym wystąpiły lub mogą wystąpić skutki tej klęski (art. 4 i art. 5 ustawy z 18 kwietnia 2002 r. o stanie klęski żywiołowej, t.j. Dz.U. 2017, poz. 1897). Wobec faktu, że nigdy wcześniej stan ten nie został ogłoszony, w praktyce skorzystanie z omawianej ulgi przez podatników staje się fikcją.

Istnienie drugiej ulgi, polegającej na obniżeniu kwoty podatku w stosunku do gruntów położonych na terenach podgórskich oraz górskich (art. 13b u.p.r.), wpisuje się w ogólny charakter tego typu danin. Zauważyć bowiem należy, że położenie gruntów oraz stopień ich nachylenia względem powierzchni w istotny sposób wpływa na potencjalną przychodowość z danego użytku rolnego. Zgodnie z obowiązującymi przepisami z powyższej preferencji korzy-

${ }^{20}$ G. de Luca, Diritto tributario, Gruppo Editoriale Simone, Napoli 2012, s. 279.

${ }^{21}$ J. Lamarque, O. Négrin, L. Ayrault, Droit fiscal, op. cit., s. 1079.

${ }_{22}$ Zob. art. 106 ust. 5 rumuńskiego kodeksu podatkowego - Lege Nr. 227/2015 din 8 septembrie 2015, Codul fiscal. 
stać mogą nie tylko podmioty, które faktycznie prowadzą na przedmiotowych gruntach działalność rolniczą, ale także te, które posiadają grunty w innym celu niż produkcja rolna.

Analizując przepisy ustawy o podatku rolnym, dostrzec można, że powyższy problem nie tylko odnosi się do wspomnianych ulg, ale także do przysługujących podatnikom zwolnień (art. 7 u.p.r.). Z założenia preferencje te zostały wprowadzone po to, aby uwzględnić zazwyczaj czasowy brak osiągania przychodu przez podmiot prowadzący działalność rolniczą lub też obniżoną zdolność danego gruntu do generowania na odpowiednim poziomie przychodu. Tymczasem z obowiązujących zwolnień może w praktyce skorzystać każdy podatnik, zarówno ten, kto prowadzi działalność rolniczą, jak i ten, który wyłącznie posiada odpowiednio sklasyfikowane w ewidencji gruntów i budynków grunty. Przyczyną takiego stanu rzeczy jest to, że mimo iż zdecydowana większość zwolnień odnosi się, z założenia, do faktu prowadzenia produkcji rolnej, to dotyczy gruntów wchodzących w skład gospodarstwa rolnego, które, jak już wskazano, mogą znajdować się w posiadaniu podmiotu nieprowadzącego działalności rolniczej.

Już tylko tych kilka opisanych aspektów opodatkowania podatkiem rolnym wydaje się uzasadniać rozważenie konieczności modyfikacji konstrukcji (a co za tym idzie charakteru prawnego) podatku rolnego. Chodzi tutaj przede wszystkim o te elementy, które wskazują na przychodowy lub przychodowo-dochodowy charakter tej daniny. Niezależnie od tego, zasadna wydaje się koncepcja stopniowego odchodzenia od stosowanej formy opodatkowania i w konsekwencji likwidacji podatku rolnego. Procesowi temu równolegle towarzyszyć powinno objęcie tego zakresu opodatkowania podatkami dochodowymi i nowym podatkiem od nieruchomości.

\section{Przychody osób fizycznych ze specjalistycznej produkcji rolnej}

Zgodnie z przepisami ustawy o podatku dochodowym od osób fizycznych wyłączone $\mathrm{z}$ opodatkowania zostały przychody uzyskiwane $\mathrm{z}$ działalności rolniczej z wyjątkiem działów specjalnych produkcji rolnej (art. 2 ust. 1 pkt 1 ustawy o podatku dochodowym od osób fizycznych). Koresponduje to z przyjętym w Polsce założeniem, że podatkiem obciążającym działalność rolniczą jest podatek rolny, a jedynie w zakresie specjalistycznej działalności rolniczej zastosowanie mają przepisy ustawy o podatku dochodowym od osób fizycznych. W związku z tym należy zwrócić szczególną uwagę na pojęcie działalności rolniczej i specjalistycznej działalności rolniczej (działów specjalnych produkcji rolnej). Zawarta w ustawie o podatku dochodowym od osób fizycznych definicja działalności rolniczej może budzić istotne wątpliwości. Przede wszystkim należy zauważyć, że w polskim systemie podatkowym występują dwie zbliżone do siebie, ale nie tożsame definicje działalności rolniczej. Pierw- 
sza w ustawach o podatkach dochodowych (art. 2 ust. 2 ustawy o podatku dochodowym od osób fizycznych), druga w ustawie o podatku rolnym (art. 2 ust. 2 u.p.r.). Sytuacja taka może powodować problemy praktyczne wówczas, gdy dana czynność uznana za działalność rolniczą w podatkach dochodowych nie będzie nią w podatku rolnym. Ponadto zauważyć należy, że istnienie dychotomii w zakresie opodatkowania działalności rolniczej podatkiem rolnym oraz podatkiem dochodowym od osób fizycznych prowadzi do tego, o czym będzie mowa niżej, że niektóre czynności mieszczące się w pojęciu definicji działalności rolniczej nie są w Polsce w ogóle opodatkowane ${ }^{23}$. W literaturze przedmiotu słusznie podkreśla się także brak precyzyjnego wskazania używanych przez ustawodawcę pojęć określających czynności, które zawierają się w definicji działalności rolniczej zawartej na gruncie ustawy o podatku dochodowym od osób fizycznych ${ }^{24}$. Dodatkowo należy zauważyć, że współcześnie w konstrukcji podatków dochodowych państw europejskich za przychód uzyskiwany z tytułu działalności rolniczej uznaje się nie tylko te kwoty, które zostały osiągnięte w związku z prowadzoną w stanie nieprzetworzonym hodowlą, chowem zwierząt lub uprawą roślin, ale także takie, które wynikają z przetworzenia produktów rolnych pochodzących z pierwotnej produkcji (np. sprzedaży wytworzonego sera, chleba, tradycyjnych wędlin, wina). Powyższa sytuacja ma miejsce jednak w tych podatkach dochodowych, kiedy przychody uzyskiwane z tytułu działalności rolniczej stanowią odrębne źródło przychodu (np. Włochy ${ }^{25}$, Francja ${ }^{26}$, Austria ${ }^{27}$, Niemcy $^{28}$ ) lub kiedy wprawdzie zaliczone są do źródła przychodów z pozarolniczej działalności gospodarczej, ale prowadzenie produkcji rolnej jest traktowane przez ustawodawcę w sposób preferencyjny (np. Czechy ${ }^{29}$, Hiszpania ${ }^{30}$, Portugalia ${ }^{31}$ ). W Polsce w związku z faktem, że przychody uzyskiwane z działalności rolniczej, poza przychodami z działów

${ }^{23}$ M. Burzec, Pojęcie działalności rolniczej na gruncie ustawy o podatku dochodowym od osób fizycznych - wnioski de lege ferenda, „Przegląd Prawa Publicznego” 2017, nr 10, s. 57 i n.

${ }^{24}$ J. Bieluk, Działy specjalne produkcji rolnej. Problemy prawne, Temida 2, Białystok 2013, s. 129-137; idem, Pojęcie działalności rolniczej w ustawach o podatku dochodowym od osób fizycznych i osób prawnych, „Przegląd Prawa Rolnego” 2008, nr 2, s. 186 i n.

${ }_{25}$ S. Pansieri, I redditi fondiari [w:] Manuale di diritto tributario, red. G. Falsitta, CEDAM - Wolters Kluwer, Padova 2015, s. 152-161.

26 P. Beltrame, La fiscalité en France, Hachette Supérieur, Paris 2012, s. 34-36.

27 W. Dorlat, Steuerrecht, MANZ, Wien 2017, s. 9.

${ }^{28}$ J. Hey, Einkommensteuer [w:] Steuerrecht, red. K. Tiepke, J. Lang, Verlag dr. Otto Schmidt KG, Köln 2015, s. 394-397.

29 I. Pařízková, Daň z př́imů fyzických osob [w:] Finanční a daňové právo, red. P. Jánošíková, P. Mrkývka, Aleš Čeněk, Plzeň 2016, s. 318-320.

${ }^{30}$ G. de la Peña Velasco, M. Navarro Egea, Impuesto sobre la Renta de las Personas Físicas [w:] Sistema fiscal español, red. G. de la Peña Velasco, R. Falcón y Tella, M.Á. Martínez Lago, Iustel, Madrid 2016, s. 57 -66.

${ }^{31}$ R.D. Morais, Sobre o IRS, Almedina, Coimbra 2010, s. 77-100. 
specjalnych produkcji rolnej, są wyłączone z opodatkowania podatkiem dochodowym oraz wobec braku wyraźnej wizji ustawodawcy co do reformy opodatkowania dochodów osiąganych z tego rodzaju działalności, rozszerzenie zakresu przedmiotowego definicji działalności rolniczej o czynności polegające na przetwarzaniu produktów roślinnych i zwierzęcych pochodzących z własnych upraw, chowu lub hodowli, nie wydaje się uzasadnione. Prowadziłoby to bowiem do jeszcze większego uprzywilejowania grupy podatników prowadzących działalność rolniczą.

Konieczność opodatkowania podatkiem dochodowym od osób fizycznych działów specjalnych produkcji rolnej wynika $\mathrm{z}$ dwóch przyczyn. Pierwszą z nich jest sposób wykorzystania gruntu (ziemi) w ramach prowadzenia określonej produkcji rolnej. Przy tradycyjnej działalności rolniczej grunt rolny traktowany jest jako środek produkcji, za którego pomocą wytwarzane są dobra wyższego rzędu, takie jak produkty roślinne lub zwierzęce. W związku z tym odgrywa niebagatelne znaczenie jakość i przydatność rolnicza gleby, stosunki wodne, rzeźba terenu czy też miejscowy agroklimat. Inaczej z kolei dzieje się, gdy grunt wykorzystywany jest jako miejsce produkcji. Wówczas czynniki takie, jak: jakość gleby, ukształtowanie terenu czy też naturalne stosunki wodne, nie odgrywają determinującego znaczenia. Drugą przyczyną (wykorzystywaną raczej uzupełniająco) jest to, że przyjmuje się, iż specjalistyczna działalność rolnicza cechuje się wyższą dochodowością. Wiąże się to także z faktem, że uniezależnienie produkcji rolnej od wspomnianych wyżej czynników produkcyjnych zmniejsza naturalne ryzyko związane z uprawami (w mniejszym stopniu $\mathrm{z}$ hodowlą lub chowem). Odmienne potraktowanie na gruncie prawa podatkowego specjalistycznej działalności rolniczej będzie miało miejsce $\mathrm{w}$ tych systemach podatkowych, gdzie podstawa opodatkowania ustalana jest przy wykorzystaniu metod uproszczonych, takich jak znamiona zewnętrzne czy tzw. dochód katastralny ${ }^{32}$.

Istotną wadą przyjętych w ustawie o podatku dochodowym od osób fizycznych rozwiązań odnoszących się do odrębnego opodatkowania specjalistycznej działalności rolniczej jest to, że katalog upraw roślin, hodowli i chowu zwierząt (art. 2 ust. 3 ustawy o podatku dochodowego od osób fizycznych) nie został skonstruowany w taki sposób, aby wszystkie czynności mieszczące się w pojęciu działalności rolniczej zostały opodatkowane. Wydaje się bowiem, że ustawodawca nie kierował się jakąkolwiek logiką przy ustalaniu katalogu specjalistycznej produkcji rolnej. Po pierwsze, do powyższego katalogu należało zaliczyć taki rodzaj upraw, hodowli i chowu, dla których czynnik ziemi jest jedynie miejscem produkcji (np. hodowla kotów i psów rasowych w ramach

${ }^{32}$ M. Burzec, Taxation of specialist agricultural activity in Poland - an attempt to evaluate the existing solutions [w:] Essential problems with taxation of agriculture, red. M. Burzec, P. Smoleń, Wydawnictwo KUL, Lublin 2017, s. 52-54. 
gospodarstwa rolnego). W tym kontekście wydaje się, że całość produkcji zwierzęcej bez względu na to, czy jest ona prowadzona w ramach gospodarstwa rolnego czy też poza nim, powinna stanowić dział specjalny produkcji rolnej. Po drugie, do działów specjalnych produkcji rolnej została zaliczona wyłącznie hodowla i chów zwierząt poza gospodarstwem rolnym i tylko tych gatunków zwierząt, które zostały wymienione w rozporządzeniu Ministra Finansów $w^{33}$. Prowadzi to do sytuacji, w której niektóre czynności mieszczące się w pojęciu działalności rolniczej nie będą podlegały opodatkowaniu ani podatkiem dochodowym od osób fizycznych (gdyż nie będą stanowiły działu specjalnego produkcji rolnej), ani podatkiem rolnym (o ile nie będą wykonywane na gruntach sklasyfikowanych w ewidencji gruntów i budynków rolnych jako użytki rolne). Okoliczność taka może mieć miejsce w przypadku prowadzenia domowej uprawy roślin ozdobnych lub akwariowych, a także hodowli lub chowu niektórych zwierząt, takich jak: ptactwo egzotyczne (np. papugi, kanarki) i ozdobne (np. bażanty, pawie), płazy (np. żaby), gady (żółwie, gekony, pytony), bezkręgowce (raki, krewetki akwariowe, ślimaki afrykańskie, ślimaki jadalne, pająki, świerszcze domowe) czy drobne ssaki (chomiki, świnki morskie). Ponadto z zakresu opodatkowania wyłączone zostały wszystkie zwierzęta laboratoryjne poza myszą białą i szczurem białym.

Wydaje się, że rozszerzenie zakresu przedmiotowego działów specjalnych produkcji rolnej byłoby możliwe, nawet bez głębszej reformy zasad opodatkowania działalności rolniczej. Obecnie wiele problemów związanych z omawianą tematyką wynika $\mathrm{z}$ istnienia $\mathrm{w}$ konstrukcji podatku norm szacunkowych dochodu rocznego dla działów specjalnych produkcji rolnej. Ich występowanie, przez konieczność precyzyjnego określenia odpowiedniej normy dla każdego rodzaju prowadzonych upraw i hodowli lub chowu zwierząt, usztywnia reguły opodatkowania tego rodzaju działalności. Przyjęte w Polsce regulacje prawne nie do końca prawidłowo różnicują normy szacunkowe dochodu rocznego. Problem ten jest szczególnie widoczny przy opodatkowaniu upraw w szklarniach, gdzie dokonano podziału produkcji rolnej na uprawy roślin ozdobnych oraz inne uprawy. Ustawodawca uzależnił wysokość osiąganych przez podatnika dochodów od tego, czy uprawy prowadzone są w szklarniach ogrzewanych czy też nie. Jednakże z przeprowadzonych badań wynika, że poziom osiąganego dochodu zależy również od tego, czy uprawa w szklarniach ma miejsce na podłożu inertnym (mineralnym) czy też na glebie macierzystej ${ }^{34}$. Nieuwzględnienie powyższych kwestii prowadzi do tego, że norma szacunkowa dochodu rocznego jest jednakowa zarówno dla nowoczesnych (uprawy na podłoży

33 Rozporządzenie Ministra Rozwoju i Finansów z 8 grudnia 2017 r. w sprawie norm szacunkowych dochodu z działów specjalnych produkcji rolnej, Dz.U. poz. 2393.

${ }^{34}$ A. Chudzik, Koszty i dochodowość produkcji pomidorów pod osłonami w zależności od technologii produkcji, „Annales Universitatis Mariae Curie-Skłodowska” 2014, t. XXIV, nr 4 , s. 43 i n. 
inertnym), jak i tradycyjnych sposobów upraw szklarniowych. Dlatego wydaje się, że zlikwidowanie możliwości ustalania podstawy opodatkowania na podstawie norm mogłoby w pewien sposób uporząakować omawiane kwestie. Pozwoliłoby tym samym ustawodawcy w sposób bardziej elastyczny niż obecnie stworzyć ostateczny katalog tych czynności związanych z produkcją roślinną i zwierzęcą, które stanowiłyby działy specjalne produkcji rolnej. Ponadto, jak się wydaje, sama rezygnacja $\mathrm{z}$ norm doprowadziłaby do tego, że na skutek braku szczegółowego przypisania szacunkowego dochodu do poszczególnych rodzajów upraw, chowu lub hodowli, doszłoby do bardziej racjonalnego opodatkowania podatników. Wysokość podatku zostałaby bowiem uzależniona od wysokości osiąganych dochodów, a nie także wielkości, rodzaju lub też sposobu prowadzonej produkcji rolnej.

\section{Kierunkowe założenia zmian opodatkowania przychodów rolniczych}

Istniejące w Polsce problemy z opodatkowaniem przychodów z działalności rolniczej prowokują do podjęcia próby wskazania kierunków zmian. Celem reformy powinno być osiągnięcie spójnego i sprawdzonego w innych krajach modelu opodatkowania działalności rolniczej. Sięgając do doświadczeń innych państw, łatwo zauważyć, że podstawowymi elementami wchodzącymi w skład każdego modelu jest podatek dochodowy oraz odrębny podatek obciążający nieruchomości rolne. Podkreślić jednak należy, że cechą odróżniającą poszczególne modele jest przede wszystkim sposób ukształtowana podstawy opodatkowania w podatku dochodowym. Wyróżnić można dwa podstawowe modele: model brytyjski oraz model kontynentalny. Model brytyjski charakteryzuje się tym, że podstawę opodatkowania w podatku dochodowym stanowią rzeczywiste dochody ustalane na podstawie dokumentacji podatkowej. Natomiast grunty rolne, o ile wykorzystywane są do produkcji rolnej, zazwyczaj są wyłączone z opodatkowania podatkiem obciążającym nieruchomości. W modelu kontynentalnym można wyróżnić trzy warianty: opodatkowanie jednolite, opodatkowanie uproszczone i opodatkowanie mieszane. Istotą modelu kontynentalnego jednolitego jest próba opodatkowania działalności rolniczej jedną daniną, która pełni jednocześnie funkcję podatku majątkowego i przychodowo-dochodowego. W modelu kontynentalnym uproszczonym obowiązują dwa podatki. Podstawę opodatkowania w podatku dochodowym ustala się zgodnie z metodami szacunkowymi, niezależnie jednak od tego grunty wykorzystywane do produkcji rolnej opodatkowane są podatkiem od nieruchomości. Natomiast w modelu kontynentalnym mieszanym podstawę opodatkowania dla małych lub średnich gospodarstw rolnych ustalana jest zgodnie z metodami szacunkowymi, natomiast dla dużych stanowi ona rzeczywiste dochody uzyskiwane przez podatników. 
Mając na uwadze polskie doświadczenia i obecne uwarunkowania, wydaje się, że docelowym modelem, który powinien zostać przyjęty w Polsce, jest model kontynentalny mieszany. Oznacza to, że dochody uzyskiwane przez podatników prowadzących działalność rolniczą powinny zostać opodatkowane podatkiem dochodowym $\mathrm{z}$ określonymi preferencjami dla małych i średnich gospodarstw rolnych. Z kolei grunty służące do produkcji rolnej należałoby objąć typowym podatkiem majątkowym nakładanym na nieruchomości.

Wydaje się, że zmiany powinny zostać rozłożone w czasie i obejmować trzy etapy. W pierwszym etapie, trwającym około 5 lat, w podatku rolnym należałoby wyraźnie zróżnicować obciążenie podatkowe w zależności od tego, czy grunty rolne będą wykorzystywane do prowadzenia działalności rolniczej (wchodziły w skład gospodarstwa rolnego) czy też nie. Osiągnięcie tego celu będzie możliwe przez wprowadzenie do konstrukcji podatku rolnego pojęcia przedsiębiorcy rolnego oraz zmianę definicji gospodarstwa rolnego, które powinno być rozumiane jako grunty sklasyfikowane w ewidencji gruntów i budynków jako użytki rolne związane z prowadzeniem działalności rolniczej. Wobec nadania nowego znaczenia pojęciu gospodarstwo rolne, niezwykle istotną kwestią wydaje się ukształtowanie na nowo definicji działalności rolniczej, która powinna być jednolita zarówno dla podatku rolnego, jak i podatków dochodowych. Powinna ona obejmować nie tylko czynności polegające na wytwarzaniu produktów roślinnych, zwierzęcych $\mathrm{w}$ stanie nieprzetworzonym $\mathrm{z}$ własnych upraw albo hodowli lub chowu, ale także czynności polegające na przetwarzaniu w sposób inny niż przemysłowy produktów roślinnych i zwierzęcych pochodzących $\mathrm{z}$ własnych upraw, hodowli i chowu. Podkreślić także należy, że cała wymieniona aktywność powinna zostać uznana za działalność rolniczą pod warunkiem, że będzie wykonywana przez podmiot mający status przedsiębiorcy rolnego (rozumianego jako osoba fizyczna, osoba prawa, jednostka organizacyjna nieposiadająca osobowości prawnej), która bez względu na rezultat prowadzi działalność rolniczą oraz która uzyskała wpis do rejestru przedsiębiorców rolnych. $\mathrm{W}$ związku $\mathrm{z}$ wprowadzeniem powyższych zmian w pierwszym etapie podatek rolny, w zależności od rodzaju podatnika przez kilka lat będzie miał dwojaki charakter. W stosunku do podatników mających status przedsiębiorców rolnych byłby to nadal podatek o charakterze przychodowo-dochodowo-majątkowym. Podatnicy będący przedsiębiorcami rolnymi nadal bowiem mogliby korzystać z dotychczasowych zwolnień podatkowych, ulgi inwestycyjnej oraz ulgi górskiej i podgórskiej. Natomiast podstawa opodatkowania powinna być wyrażona w hektarach przeliczeniowych. Zmianie powinien ulec sposób ustalania wysokości stawki podatkowej np. przez odejście od ceny żyta na rzecz koszyka powszechnie stosowanych w Polsce upraw ustalonych na podstawie specjalnie do tego przystosowanego algorytmu. Ponadto zlikwidowaniu ulec powinna ulga z tytułu klęski żywiołowej mimo istotnej roli, jaką powinna odgrywać w konstrukcji podatków takich jak podatek rolny. 
W przypadku podatników, którzy nie będą mieli statusu przedsiębiorcy rolnego, podatek rolny powinien mieć charakter podatku majątkowego. Podatnicy ci mogliby skorzystać wyłącznie ze zwolnień w stosunku do tych gruntów, którymi z przyczyn niezależnych od siebie nie mogliby swobodnie dysponować (np. położonych w pasie drogi granicznej, stanowiących użytki ekologiczne, znajdujących się pod wałami przeciwpowodziowymi lub przy zbiornikach wody służących do zaopatrzenia ludności w wodę). Ponadto podatnicy niebędący przedsiębiorcami rolnymi nie mogliby skorzystać z ulg podatkowych w podatku rolnym. Podstawę opodatkowania stanowiłaby powierzchnia wyrażona w hektarach fizycznych.

Równolegle w konstrukcji podatku dochodowego od osób fizycznych należałoby wprowadzić zmiany odnoszące się do wprowadzenia tożsamej z występującą w ustawie o podatku rolnym definicji działalności rolniczej. Oprócz tego konieczne stają się likwidacja norm szacunkowych dochodu rocznego w działach specjalnych produkcji rolnej oraz rozszerzenie katalogu tzw. innych źródeł o prowadzenie hodowli i chowu zwierząt oraz uprawy roślin, które nie mieszczą się w definicji działalności rolniczej.

W drugim etapie podatek rolny powinien stać się daniną o charakterze majątkowym, pozbawioną elementów przychodowo-dochodowych. Celem byłoby zerwanie $\mathrm{z}$ dychotomią podatku rolnego wprowadzoną na etapie pierwszym, która przejawiała się istnieniem odrębnych zasad opodatkowania gruntów wchodzących w skład gospodarstwa rolnego (znajdujących się w posiadaniu przedsiębiorcy rolnego) i gruntów niestanowiących gospodarstwa rolnego. Oznacza to, że podatek rolny w nowej konstrukcji powinien obciążać wyłącznie grunty sklasyfikowane w ewidencji gruntów i budynków jako użytki rolne, które są związane z prowadzeniem działalności rolniczej (tzn. będące w posiadaniu przedsiębiorcy rolnego). Natomiast grunty sklasyfikowane w ewidencji gruntów i budynków jako użytki rolne, które w pierwszym etapie reformy nie wchodziły w skład gospodarstwa rolnego (czyli nie były w posiadaniu przedsiębiorcy rolnego), powinny zostać wyłączone z opodatkowania podatkiem rolnym i stanowić przedmiot opodatkowania w podatku od nieruchomości. W celu zapewnienia podatkowi rolnemu charakteru majątkowego, zlikwidowaniu powinny ulec te zwolnienia gruntów, które w jakikolwiek sposób odnoszą się do wykorzystywania ich na cele rolnicze (np. zwolnienie użytków rolnych klasy V, VI i VIz, gruntów gospodarstw rolnych powstałych z zagospodarowania nieużytków; gruntów gospodarstw rolnych otrzymanych w drodze wymiany lub scalenia). W konstrukcji podatku rolnego powinny pozostać zwolnienia odnoszące się do tych gruntów, którymi podatnik z przyczyn niezależnych od niego nie może swobodnie dysponować. Zlikwidowaniu powinny ulec ulgi. Podstawę opodatkowania powinna stanowić powierzchnia wyrażona w hektarach fizycznych.

Konsekwencją modyfikacji charakteru prawnego podatku rolnego (wyłącznie jako daniny o charakterze majątkowym) byłaby konieczność opodatkowa- 
nia podatkiem dochodowym przychodów uzyskiwanych z tytułu prowadzenia działalności rolniczej. Powinno to nastąpić zarówno na gruncie podatku dochodowego od osób fizycznych, jak i podatku dochodowego od osób prawnych. Dodać należy, że przychody z działalności rolniczej powinny stanowić odrębne źródło przychodów. Jednocześnie do przychodów z innych źródeł powinny zostać zakwalifikowane te kwoty, które uzyskiwane są przez tych podatników, którzy nie mają statusu przedsiębiorcy rolnego, ale wykonywane przez nich czynności mieszczą się w ramach definicji działalności rolniczej (np. hodowla zwierząt egzotycznych, psów czy kotów rasowych). Objęcie zakresem przedmiotowym w podatku dochodowym od osób fizycznych działalności rolniczej będzie prowadziło do tego, że zbędne stanie się odrębne opodatkowanie specjalistycznej działalności rolniczej. Stąd też działy specjalne produkcji rolnej powinny zostać zlikwidowane, a przychody uzyskane ze specjalistycznych upraw roślin, hodowli i chowu zwierząt przez podmiot mający status przedsiębiorcy rolnego stanowiłyby przychody z działalności rolniczej. Podstawę opodatkowania dla podatników prowadzących działalność rolniczą powinien stanowić dochód ustalany na podstawie dokumentacji podatkowej. Oznacza to, że podatnicy prowadziliby uproszczoną dokumentację podatkową w postaci podatkowej księgi przychodów i rozchodów oraz pełną dokumentację podatkową w postaci księgi rachunkowej. Obowiązek prowadzenia pełnej dokumentacji podatkowej istniałby wówczas, gdy przychody podatnika za rok poprzedzający rok podatkowy wyniosłyby w walucie polskiej co najmniej równowartość kwoty 2000000 euro. Preferencyjnym rozwiązaniem, skierowanym do podatników prowadzących działalność rolniczą powinna być możliwość ustalenia ryczałtowych kosztów uzyskania przychodów. Niemniej z powyższej preferencji powinni korzystać tylko ci przedsiębiorcy rolni, których przychody w roku poprzedzającym rok podatkowy nie przekroczą 200000 złotych. Wysokość ryczałtowych kosztów uzyskania przychodu winna wynosić od $80 \%$ do $90 \%$ uzyskanego przychodu. Po pierwsze, wynika to z wysokich kosztów związanych z produkcją rolną. Po drugie, ustalenie ryczałtowych kosztów na nieco wyższym poziomie powinno złagodzić dolegliwość opodatkowania dochodów uzyskiwanych z prowadzonej działalności rolniczej przez przedsiębiorców rolnych osiąganych przez średnie gospodarstwa rolne (a także w mniejszym stopniu przez małe gospodarstwa).

W stosunku do podatników, którzy nie skorzystają z prawa ustalania ryczałtowych kosztów, zastosowanie powinny mieć regulacje przyjęte dla podmiotów prowadzących pozarolniczą działalność gospodarczą. Tym samym za koszty uzyskania przychodu zostaną uznane koszty poniesione w celu osiągnięcia przychodów lub zachowania albo zabezpieczenia źródła przychodów $\mathrm{z}$ wyjątkiem tych kosztów, które zostały enumeratywnie wymienione w art. 23 ustawy o podatku dochodowym od osób fizycznych. W tak ustalonych kosztach uzyskania przychodu powinien mieścić się także zapłacony podatek rolny. 
Konsekwencją ustalenia rzeczywistych kosztów uzyskania przychodów będzie możliwość skorzystania $\mathrm{z}$ amortyzacji środków trwałych.

Przedmiotem amortyzacji powinien być nie tylko inwentarz martwy, ale także zwierzęta oraz plantacje roślin o okresie użytkowania przekraczającym trzy lata. Ponadto podatnikom mającym status przedsiębiorcy rolnego powinna przysługiwać dodatkowa preferencja podatkowa, polegająca na zwolnieniu $\mathrm{z}$ opodatkowania dochodu, który zostanie w całości lub części przeznaczony na wskazane w ustawie inwestycje. Ze zwolnienia będzie mógł skorzystać przedsiębiorca rolny, który całość lub część uzyskanego dochodu przeznaczy na inwestycje polegające na: zakupie gruntów rolnych; budowie, rozbudowie, modernizacji, remoncie budynków służących do prowadzenia działalności rolniczej zarówno w zakresie produkcji roślinnej, jak i zwierzęcej; zakupie nowych środków trwałych (maszyn rolniczych). Zwolnienie powinno przysługiwać przedsiębiorcom rolnym raz na 3-5 lat. Z opodatkowania powinien zostać zwolniony dochód uzyskany z tytułu prowadzonej działalności rolniczej w wysokości, która odpowiada iloczynowi tego dochodu i udziału wydatków inwestycyjnych w majątek służący do prowadzenia działalności rolniczej dokonanych przez producenta rolnego w przychodzie z działalności rolniczej. Ponadto zwolnione z opodatkowania podatkiem dochodowym powinny zostać także dopłaty do produkcji rolnej otrzymywane przez przedsiębiorców rolnych.

Wprowadzenie trzeciego etapu reformy oznaczać będzie osiągnięcie docelowego modelu opodatkowania działalności rolniczej. Podkreślić należy, że o ile zasady opodatkowania dochodów przyjęte w drugim etapie reformy nie ulegną zmianie, o tyle $\mathrm{w}$ zakresie opodatkowania gruntów służących do prowadzenia działalności rolniczej istotną zmianą będzie likwidacja podatku rolnego. Tym samym grunty związane z prowadzeniem działalności rolniczej, czyli posiadane przez przedsiębiorcę rolnego, będą stanowily przedmiot opodatkowania $w$ podatku od nieruchomości (w którym podstawą opodatkowania mogłaby być wartość). Wdrożenie trzeciego etapu należałoby powiązać $\mathrm{z}$ wprowadzeniem w Polsce kompleksowej reformy opodatkowania nieruchomości (ad valorem).

\section{Bibliografia}

Achard A., Les prélèvements obligatories sur l'exploatation agricole, Educagri, Dijon 2009.

Aghata M., Einkünfte aus Land- und Forstwirtschaft [w:] Besteuerung der Land- und Forstwirtschaft, red. M. Aghata i in., La fiscalité en France, Hachette Supérieur, Paris 2012.

Bieluk J., Cena żyta jako miernik wysokości podatku rolnego, „Studia Iuridica Agraria” 2000, nr 1 .

Bieluk J., Działy specjalne produkcji rolnej. Problemy prawne, Temida 2, Białystok 2013. 
Bieluk J., Pojęcie działalności rolniczej w ustawach o podatku dochodowym od osób fizycznych i osób prawnych, „Przegląd Prawa Rolnego” 2008, nr 2.

Burzec M., Pojęcie działalności rolniczej na gruncie ustawy o podatku dochodowym od osób fizycznych - wnioski de lege ferenda, „Przegląd Prawa Publicznego” 2017, nr 10.

Burzec M., Taxation of specialist agricultural activity in Poland - an attempt to evaluate the existing solutions [w:] Essential problems with taxation of agriculture, red. M. Burzec, P. Smoleń, Wydawnictwo KUL, Lublin 2017.

Chudzik A., Koszty i dochodowość produkcji pomidorów pod osłonami w zależności od technologii produkcji, „Annales Universitatis Mariae Curie-Skłodowska” 2014, t. XXIV, 2014, nr 4.

D’Amati N., La legge sulla perequazione fondiaria e l'emergere del reddito agrario [w:] L'impresa agraria tra fisco, problem ambientali e programmazione territoriale, red. N. D’Amati, Cacucci Editore, Bari 2006.

Dorlat W., Steuerrecht, MANZ, Wien 2017.

Główny Urząd Statystyczny, Rolnictwo w 2015 roku, Warszawa 2016.

Gorgol A., Revenue factor as a feature of the agricultural tax [w:] Essential problems with taxation of agriculture, red. M. Burzec, P. Smoleń, Wydawnictwo KUL, Lublin 2017.

Hanusz A., Czerski P., Gminne podatki i opłaty lokalne, Zakamycze, Kraków 2004.

Hanusz A., Polityka podatkowa w zakresie różnicowania obciążeń dochodów rolniczych w Polsce. Na przykładzie podatków gruntowego i rolnego, Wydawnictwo UMCS, Lublin 1996.

Hey J., Einkommensteuer [w:] Steuerrecht, red. K. Tipke, J. Lang, Verlag dr. Otto Schmidt KG, Köln 2015.

Lamarque J., Négrin O., Ayrault L., Droit fiscal général, LexisNexis, Paris 2016.

Luca G. de, Diritto tributario, Gruppo Editoriale Simone, Napoli 2012.

Morais R.D., Sobre o IRS, Almedina, Coimbra 2010.

Muleo S., Impresa agraria ed imposizione reddituale, Giuffrè Editore, Milano 2005.

Pansieri S., I redditi fondiari [w:] Manuale di diritto tributario, red. G. Falsitta, CEDAM - Wolters Kluwer, Padova 2015.

Pařízková I., Daň z príjmů fyzických osob [w:] Finanční a daňovéprávo, red. P. Jánošíková, P. Mrkývka, Aleš Čeněk, Plzeň 2016.

Pauličková A., Priame dane v Slovenskej republike, Eurounion, Bratislava 2001.

Peña Velasco G. de la, Navarro Egea M., Impuesto sobre la Renta de las Personas Físicas, [w:] Sistema fiscal español, red. G. de la Peña Velasco, R. Falcón y Tella, M.Á. Martínez Lago, Iustel, Madrid 2016.

Peyerl H., Unternehmensgründung und laufende Unternehmensführung [w:] Rechtsformwahl in der Land- und Forstwirtschaft. Gestalung und Besteuerung, P. Brauner, H. Peyerl, W. Pum, C. Urban, Verlag Österreich, Wien 2015.

Pietrasiewicz W., Podatek rolny [w:] Prawo podatkowe przedsiębiorców, red. H. Litwińczuk, Wolters Kluwer, Warszawa 2013.

Podatki przychodowo-dochodowo-majatkowe [w:] System prawa finansowego, t. 3, red. L. Etel, C.H. Beck, Warszawa 2010. 
Reniger H., Problem podstawy wymiaru w socjalistycznym podatku rolniczym okresu przejściowego, Państwowe Wydawnictwo Naukowe, Torun 1963.

Steurergesetze 2012, Boorberg, Stuttgart 2012.

Taylor E., Reforma podatku gruntowego w Polsce, S.A. Krzyżanowski, Kraków 1919.

Veen H. van der, Meulen H. van der, Bommel K. van, Doorneweert B., Exploring agricultural taxation in Europe, LEI, Haga 2007. 